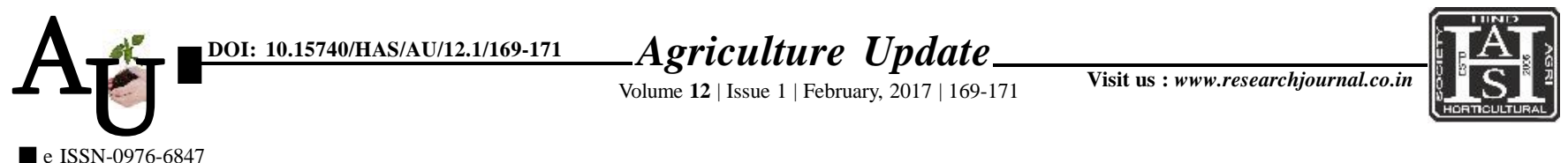

\title{
Research Note: Economic impact of front line demonstrations on finger millet yields
}

\section{K.S. SHUBHASHREE, C.R. RAVISHANKAR, H.R. RAVEENDRA AND K. MADHUSUDHAN}

Article Chronicle :

SUMMARY : A study was conducted for two years during 2014-15 and 2015-16 involving 30 and 15

Received :

26.09.2016;

Accepted :

26.01.2017

farmers at Tumkur and Ramanagara districts, respectively. The improved finger millet variety KMR-301 and KMR-204 were used to demonstrate the improved production technology on finger millet in the farmer's field. The data revealed that during 2014 by the introduction of new technology the grain yield was increased by 36 per cent over farmers practice and during 2015, at Ramanagara district the yield improvement was to the tune of 16 per cent.

How to cite this article : Shubhashree, K.S., Ravishankar, C.R., Raveendra, H.R. and Madhusudhan, K. (2017). Economic impact of front line demonstrations on finger millet yields. Agric. Update, 12(1): 169-171; DOI : 10.15740/HAS/AU/12.1/169-171.
KeY Words :

Front line demonstrations, Farmers practice, Finger millet, Improved variety

Author for correspondence :

K.S. SHUBHASHREE All India Coordinated Research Project on Small Millets, Zonal Agricultural Research Station, MANDYA (KARNATAKA) INDIA

Email:ks.shubhashree@ gmail.com

See end of the article for authors' affiliations 